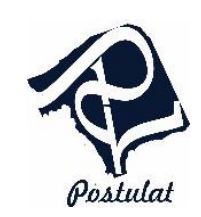

Jurnal Inovasi Pendidikan Matematika

Volume 1, Nomor 2, Desember 2020

\title{
Analisis Kemampuan Komunikasi Matematis Peserta Didik SD Dalam Menyelesaikan Soal Matematika Ditinjau Dari Kecerdasan Emosional
}

\author{
Lisa Cahyanti ${ }^{1}$, Sarwo Edy ${ }^{2}$, \\ Pendidikan Matematika, FKIP,Universitas Muhammadiyah Gresik ${ }^{1}$; Jl. Sumatera No. 101 GKB Gresik, Jawa \\ Timur Indonesia 61121; lisacahyanti306@gmail.com \\ Pendidikan Matematika, FKIP,Universitas Muhammadiyah Gresik ${ }^{2}$; Jl. Sumatera No. 101 GKB Gresik, Jawa \\ Timur Indonesia 61121; $\underline{\text { sarwo@umg.ac.id }}$
}

\begin{abstract}
One of the goals of mathematics is to communicate ideas by using symbols, tables, diagrams, or other media to explain problems or circumstances. Based on the objectives of mathematics learning, the mathematical communication skills of students need to be considered. But many students have difficulty communicating to their mathematical understanding. This is influenced by several factors, one of them is the emotional intelligence of students. This type of research is descriptive with a qualitative approach that aims to describe how students' mathematical communication skills in solving mathematical problems based on the level of emotional intelligence. The subjects of this research are the IVC grade students elementary school of Muhammadiyah Manyar in the academic year 2019 - 2020. This study consists of three students consisting of one student who has high emotional intelligence, one student who has moderate emotional intelligence, and one student who has low emotional intelligence. The methods used in this study are emotional intelligence questionnaire, students' mathematical communication skills test, and interviews. The results of the study indicate that students who have high emotional intelligence have high mathematical communication skills that are also able to illustrate the picture completely, solve coherently and correctly, and provide conclusions correctly. Students with a moderate level of emotional intelligence, have moderate mathematical communication skills, are able to illustrate almost exact and complete images, are able to finish coherently, and are not careful about answers that have been written. Students with low levels of emotional intelligence, have low mathematical communication skills, are able to illustrate almost exact images, find it difficult to write down information that is known and asked, and do not provide conclusions on answers.
\end{abstract}

Keywords: Emotional Intelligence, Mathematical Communication Skills

\begin{abstract}
Abstrak
Salah satu tujuan mata pelajaran matematika yaitu mengkomunikasikan gagasan dengan menggunakan simbol, tabel, diagram, ataupun media lain untuk memperjelaskan masalah atau keadaan. Berdasarkan dari tujuan pembelajaran matematika tersebut, maka kemampuan komunikasi matematis peserta didik perlu diperhatikan. Akan tetapi banyak peserta didik yang mengalami kesulitan dalam mengkomunikasikan pemahaman matematika mereka. Hal tersebut dipengaruhi oleh beberapa faktor, salah satunya yaitu kecerdasan emosional
\end{abstract}


peserta didik. Jenis penelitian yang digunakan yaitu deskriptif dengan pendekatan kualitatif yang bertujuan untuk mendeskripsikan bagaimana kemampuan komunikasi matematis peserta didik dalam menyelesaikan soal matematika berdasarkan tingkat kecerdasan emosional. Subjek penelitian ini yaitu peserta didik kelas IVC SD Muhammadiyah Manyar tahun ajaran 2019 - 2020. Penelitian ini terdapat tiga peserta didik yang terdiri dari satu peserta didik yang memiliki kecerdasan emosional tinggi, satu peserta didik yang memiliki kecerdasan emosional sedang, dan satu peserta didik yang memiliki kecerdasan emosional rendah. Metode yang digunakan dalam penelitian ini yaitu angket kecerdasan emosional, tes kemampuan komunikasi matematis peserta didik, dan wawancara. Hasil dari penelitian menunjukkan bahwa peserta didik yang memiliki kecerdasan emosional tinggi memiliki kemampuan komunikasi matematis yang tinggi pula yang mampu mengilustrasikan gambar dengan lengkap, menyelesaikan dengan runtut dan benar, dan memberi kesimpulan jawaban dengan benar. Peserta didik dengan tingkat kecerdasan emosional sedang, memiliki kemampuan komunikasi matematis yang sedang, mampu mengilustrasikan gambar hampir tepat dan lengkap, mempu menyelesaikan dengan runtut, dan kurang teliti atas jawaban yang telah ditulis. Peserta didik dengan tingkat kecerdasan emosional rendah, memiliki kemampuan komunikasi matematis yang rendah, mampu mengilustrasikan gambar hampir tepat, sulit menuliskan dalam menyebutkan informasi yang diketahui dan ditanya, dan tidak memberikan kesimpulan jawaban.

Kata kunci: Kecerdasan Emosional, Kemampuan Komunikasi Matematis

INFO ARTIKEL

ISSN $: 2733-0597$
e-ISSN $: 2733-0600$
DOI $:$ http://dx.doi.org/10.30587/postulat.v1 i2.2108

Submit Artikel:

2 Oktober 2020

Submit Revisi:

1 November 2020

Upload Artikel:

5 Desember 2020

\section{PENDAHULUAN}

Dalam pandemi Covid-19 semua orang telah diuji dengan keadaan seperti ini baik bidang ekonomi, sosial budaya, maupun pendidikan. Dimana semua orang harus membatasi social distancing, akan tetapi tidak membatasi dalam hal belajar untuk kemajuan pendidikan.

Karena pendidikan merupakan salah satu sebagai titik fondasi kemajuan suatu bangsa, bangsa tidak bisa dikatakan maju jika pendidikan yang dimilikinya tidak kuat. Hal ini sebagai langkah awal untuk peserta didik melatih kemampuannya dari hal membaca, menghitung, berfikir, bahkan memecahkan masalah. Sebagai salah satu pelajaran yang terkait dengan karakteristik itu adalah matematika.

Secara fungsional dalam mempelajari matematika diperlukan beberapa kemampuan seperti memahami teks matematika, istilah, teori, alat, serta prosedur dalam memecahkan masalah matematika. Hal tersebut karena adanya kemampuan komunikasi antar pendidik dan 
peserta didik. Adapun indikator kemampuan komunikasi matematis peserta didik NCTM (2000:214) menyatakan indikator tersebut yaitu (a) Mengekspresikan ide - ide matematika dengan berbicara,menulis, menunjukkan dan menggambarkan secara visual. (b) Memahami, menafsirkan, dan mengevaluasi matematika dalam bentuk ide - ide yang disajikan secara tertulis, lisan, atau visual. (c) Menggunakan bentuk - bentuk kosakata notasi, dan struktur mewakili ide - ide, menggambarkan hubungan, dan pembuatan model.

Pentingnya komunikasi matematis secara tertulis menurut Mahmudi (2006) yaitu peserta didik dapat menyelesaikan soal dengan baik ketika komunikasi tulis berbentuk uraian dan mengetahui kata-kata, tabel, alat, yang menggambarkan dalam bentuk tulis, serta menggambarkan kemampuan peserta didik dalam mengorganisasikan berbagai konsep untuk menyelesaikan permasalahan yang terkait komunikasi matematis. Kemampuan komunikasi matematis bisa dipengaruhi faktor-faktor pada diri peserta didik (intern) maupun luar diri peserta didik (ekstn). Untuk faktor dari dalam peserta didik antara lain faktor fisiologis dan psikologis. Salah satu faktor yang berpengaruh pada dalam diri peserta didik pada pemahaman komunikasi matematis yaitu kecerdasan emosional. Goleman mengatakan bahwa, " emosi yaitu suatu dorongan dalam bertindak, serta suatu perencanaan seketika untuk mengatasi masalah yang ditanamkan secara berangsur".

kecerdasan emosional (Emotional Quotient) yaitu kemampuan mengenali, memahami, memantau, mengendalikan seseorang untuk mengatur kehidupan dalam emosinya dengan intelegensinya (to manage our emotional life with intelligence) dan mengelola perasaan sendiri dan orang lain untuk memandu pikiran dan tindakan demi mencapai tujuan yang dikehendaki serta menjaga selarasan emosi dan ungkapannya (the appropriateness of emotional and it's exression) (Goleman, 2015: 55). Pendapat tersebut juga dikemukakan oleh Cooper dan Sawaf dalam (Efendi, 2005) "Emotional Intelligences the ability the understand, sense, and affectively apply the power and acumen of emotions as source of human energy, connection, information, and influence " yang artinya bahwa kecerdasan emosional merupakan kemampuan memahami, merasakan, dan efektif saat mengaplikasikan kekuatan serta 
Lisa Cahyanti ${ }^{1}$, Sarwo Edy ${ }^{2}$ : Analisis Kemampuan Komunikasi Matematis...

kecerdasan emosional sebagai sebuah sumber energi manusia, hubungan, informasi, dan pengaruh.

Berdasarkan hasil obsevasi di SD Muhammadiyah Manyar kelas IVC menunjukkan bahwa ada beberapa peserta didik yang tidak mengerjakan soal dengan sungguh-sungguh saat tidak memperoleh bimbingan dari seorang pendidik. Saat mereka tidak mengetahui cara menyelesaikan soal tersebut. Mereka mencari penyelesaian di buku tetapi mereka cenderung mengerjakan asal-asalan. Hal tersebutlah bahwa peserta didik masih kurang mendapatkan motivasi diri sendiri supaya bisa menyelesaikan soal serta memahami soal matematika. Selain itu ada yang peserta didik semangat dalam mengerjakan dikarenakan mereka suka dengan materi soal tersebut. Berdasarkan wawancara dengan guru didapatkan informasi ketika peserta didik mengalami masalah dengan temannya peserta didik juga cenderung tidak fokus dengan pembelajaran yang telah disampaikan, dikarenakan mereka tidak bisa mengkondisikan suasana hati yang sedih mereka ketika ada permasalahan dengan pelajaran yang sedang berlangsung. Yang mengakibatkan ketidak fokusan dalam menerima pembelajaran. Padahal sebenarnya peserta didik tersebut mampu memahami materi dalam pembelajaran tersebut. Namun karena rasa sedih sehingga malas peserta didik tidak mendengarkan pembelajaran akibatnya peserta didik tersebut juga tidak menyelesaikan soal matematika tersebut. Hal tersebut karena faktor pada diri peserta didik suasana hati peserta didik yang belum bisa menahan suatu emosi saat ada masalah pada waktu pembelajaran berlangsung.

Penyebab permasalahan tersebut yaitu belum bisa menahan suatu emosi sehingga mempengaruhi suasana hati peserta didik, serta perlunya motivasi diri sendiri untuk mengembangkan dirinya serta menyesuaikan dalam bertindak maka diperlukan dalam mengembangkan kecerdasan emosional. Sebab kecerdasan emosional seseorang mempengaruhi peserta didik saat menyelesaikan soal matematika. Hal itu juga diungkapkan ketika Noriah et al. (2004) melakukan penelitian dikalangan orang malaysia menunjukkan bahwa EI memiliki hubungan positif dengan kemampuan kognitif seseorang dalam kemampuan komunikasi matematis untuk menyelesaikan tugas.

Peneliti mengambil judul “Analisis kemampuan komunikasi matematis Peserta Didik SD dalam menyelesaikan soal matematika ditinjau dari kecerdasan emosional" dengan tujuan 
untuk mendeskripsikan kemampuan komunikasi matematis Peserta Didik SD dalam menyelesaikan soal matematika dengan kecerdasan emosional tinggi, sedang, dan rendah.

\section{METODE PENELITIAN}

Jenis penelitian ini yang digunakan yaitu penelitian deskriptif dengan pendekatan kualitatif. Subjek penelitian ini adalah peserta didik kelas IV C SD Muhammadiyah Manyar berjumlah sebanyak 26 peserta didik. Penelitian ini dilaksanakan pada semester genap tahun pelajaran 2019-2020.

Rancangan penelitian ini merupakan suatu tahapan ketika melakukan penelitian mulai dari awal sampai akhir penelitian berlangsung. Tahap rancangan penelitian ini yaitu:

\section{Tahap persiapan}

Tahap ini yang dilakukan yaitu menyusun proposal penelitian, menyiapkan instrumen antara lain angket kecerdasan emosional, soal-soal tes, dan pedoman wawancara.

\section{Tahap pemilihan subjek penelitian}

Subjek penelitian ini yaitu 26 peserta didik kelas IV C yang telah mempelajari materi luas bangun ruang. Dalam menentukan subjek penelitian ini diawali dengan mengerjakan angket kecerdasan emosional, melalui angket tersebut peneliti akan mengelompokkan peserta didik berdasarkan tingkat kecerdasan emosional tersebut yaitu tinggi, sedang, dan rendah. Berdasarkan pada teknik pengambilan sempelnya yaitu purposive sampling. Untuk tingkat kecerdasan emosional yang tergolong tinggi diambilkan skor tertinggi dari beberapa peserta didik yang dalam tingkat kecerdasannya tinggi,untuk tingkat kecerdasan emosional yang tergolong sedang diambilkan dari skor tengah kecerdasan emosional, Untuk tingkat kecerdasan emosional yang tergolong rendah diambilkan skor terendah dari beberapa peserta didik yang dalam tingkat kecerdasannya rendah.

\section{Tahap pengumpulan data}

Tahapan yang akan dilakukan oleh peneliti yaitu mengumpulkan data berupa angket kecerdasan emosional. Dari data deperoleh skor subjek penelitian yang akan dikelompokkan berdasarkan tingkat kecerdasan emosional tinggi, sedang, dan rendah. Hasil pengelompokan itu didapatkan tiga subjek penelitian yaitu satu peserta didik dengan kecerdasan emosional tinggi, satu peserta didik dengan kecerdasan emosional sedang, satu 
Lisa Cahyanti ${ }^{1}$, Sarwo Edy ${ }^{2}$ : Analisis Kemampuan Komunikasi Matematis...

peserta didik dengan kecerdasan emosional rendah. Kemudian melakukan tes tulis kepada subjek yang diteliti dengan soal kemampuan komunikasi matematis. Selanjutnya peneliti akan melakukan sebuah wawancara kepada tiga subjek penelitian itu.

4. Tahap analisis data

Pada tahapan ini yang dilakukan yaitu menganalisis data hasil tes penyelesaian soal kemampuan komunikasi matematis dan hasil data wawancara.

5. Tahap penyusunan laporan akhir hasil dari penelitian.

Penyusunan laporan ini setelah melakukan analisis penelitian.

Ada beberapa instrumen yang digunakan pada penelitian ini yaitu 1) Angket kecerdasan enosional, yang digunakan untuk mengetahui tingkat kecerdasan emosional peserta didik tinggi, sedang, dan rendah. Angket kecerdasan emosional yang digunakan peneliti yaitu disusun oleh Satriani (2015) yang telah dimodifikasi. 2) Tes kemampuan komunikasi matematis, soal berupa soal essay yang berdasarkan dengan indikator kemampuan komunikasi matematis. Tes bertujuan untuk memperoleh jawaban dari penyelesaian peserta didik serta mendeskripsikan analisis kemampuan komunikasi matematis dalam menyelesaikan soal matematika. Untuk mengetahui instrumen tersebut layak digunakan maka akan dilakukan sebuah uji validitas dan reliabilitas.

3) Pedoman wawancara, berisikan pertanyaan-pertanyaan untuk menggali informasi lebih lengkap mengenai jawaban peserta didik pada saat tes dari awal sampai akhir jawaban, dan digunakan untuk mendeskripsikan kemampuan komunikasi matematis peserta didik dalam menyelesaikan soal matematika.

Selain itu juga ada beberapa metode pengumpulan data yang digunakan dalam penelitian ini adalah 1) Metode Angket, metode ini diberikan kepada peserta didik sebelum pemberian soal untuk memperoleh data mengenai kecerdasan emosional peserta didik. Angket tersebut diperkenalkan oleh Goleman berdasarkan lima dimensi kecerdasan emosional. 2) Metode Tes, Metode ini digunakan untuk memperoleh data mengenai tes dalam menyelesaikan soal kemampuan komunikasi matematis, tes terdiri 3 (tiga) soal uraian. Dalam Menghitung skor akhir seluruh indikator kemampuan komunikasi matematis peserta didik dengan rumus: 


$$
\text { skor akhir }=\frac{\text { jumlah skor seluruh indikator yang diperoleh }}{\text { skor maksimal }} \times 100
$$

(Sudjana, 2005)

3) Metode Wawancara, Metode ini digunakan untuk memperoleh informasi yang lebih lengkap dan jelas mengenai penyelesaian jawaban soal tes serta digunakan untuk mendeskripsikan kemampuan komunikasi matematis peserta didik dalam mengerjakan soal tes tersebut.

Selanjutnya ada beberapa teknik analisis data yang digunakan dalam penelitian ini adalah 1) Angket Kecerdasan Emosional, Tingkat kecerdasan peserta didik diperoleh dari tes hasil jawaban pada angket yang menyesuaikan skor angket kecerdasan emosional peserta didik dengan acuan kategori tingkat kecerdasan emosional sebagai berikut,

\section{Tabel 1 Kategori Kecerdasan Emosional}

\begin{tabular}{|c|c|}
\hline Rentang Skor & Kategori Kecerdasan Emosional \\
\hline $25 \leq$ skor $<50$ & Rendah \\
\hline $50 \leq$ skor $<75$ & Sedang \\
\hline $75 \leq$ skor $<100$ & Tinggi \\
\hline
\end{tabular}

(Charankumar, 2015)

Peserta didik diminta untuk mengisi angket melalui google formulir yang telah diberikan melalui online dengan memilih satu pilihan jawaban yang telah tersedia. Kriteria pada jawaban angket terdiri atas Sangat Setuju (SS), Setuju (S), Tidak Setuju (TS), dan Sangat Tidak Setuju (STS). Untuk pemberian skor yaitu Sangat Setuju (4), Setuju (3), Tidak Setuju (2), dan Sangat Tidak Setuju (1). 2) Tes Kemampuan Komunikasi Matematis, Langkah langkah dalam menganalisisnya yaitu a. Mengoreksi hasil kemampuan komunikasi matematis berdasarkan alternatif jawaban yang telah dibuatnya. b. Menyesuaikan hasil tes kemampuan komunikasi matematis berdasarkan indikator yang dicapai

Tabel 2 Kriteria Skor Tes Kemampuan Komunikasi Matematis

\begin{tabular}{|c|c|}
\hline $\begin{array}{c}\text { Interval Skor Tes Kemampuan } \\
\text { Komunikasi Matematis }\end{array}$ & Kategori \\
\hline $80 \leq$ Nilai $\leq 100$ & Kemampuan Komunikasi Tinggi \\
\hline $65 \leq$ Nilai $\leq 80$ & Kemampuan Komunikasi Sedang \\
\hline
\end{tabular}


Lisa Cahyanti ${ }^{1}$, Sarwo Edy ${ }^{2}$ : Analisis Kemampuan Komunikasi Matematis...

\begin{tabular}{l|l}
$0 \leq$ Nilai $<65$ & Kemampuan Komunikasi Rendah
\end{tabular}

(Ahmad dan Dwi Putri N, 2018)

3) Wawancara, Analisis data didapatkan dari Triagulasi sumber data peserta didik yang telah ditentukan berdasarkan kategori kecerdasan emosional tinggi, sedang, dan rendah. Dalam Triagulasi sumber data ini akan dilakukan untuk mengetahui keabsahan data.

\section{HASIL PENELITIAN}

Disajikan hasil analisis mengenai kemampuan komunikasi matematis peserta didik SD dalam menyelesaikan soal matematika ditinjau dari kecerdasan emosional. sebagai berikut:

\section{1) Deskripsi Tahap Persiapan Penelitian}

Tahap persiapan penelitian dilakukan untuk mempersiapkan segala kebutuhan yang berhubungan dengan penelitian ini. Tahap persiapan ini terdiri dari: a) Koordinasi jadwal kegiatan penelitian, Penelitian ini dilaksanakan pada tanggal 18 Juni 2020 sampai 19 Juni 2020 di kelas IV SD Muhammadiyah Manyar pada tahun ajaran 2019 - 2020. b) Penyusunan instrumen penelitian yang terdiri dari (1) Angket kecerdasan emosional, angket diberikan kepada peserta didik angket tersebut dibuat melalui google formulir. (2) Tes kemampuan komunikasi matematis, sebelum soal tes kemampuan komunikasi digunakan, peneliti juga melakukan validasi kepada tenaga ahli yaitu satu dosen pendidikan matematika UMG dan satu pendidik matematika SD Muhammadiyah Manyar. Selain itu, peneliti juga melakukan uji soal kepada peserta didik dengan melakukan validitas dan reabilitas untuk mengetahui instrumen tersebut layak digunakan. Hasil uji vaiditas melalui SPSS 16.0 dapat dilihat pada tabel berikut:

Berikut ini tabel yang menyatakan dari hasil perhitungan SPSS r-hitung dengan rtabel:

Tabel 4

Hasil Uji Validitas

\begin{tabular}{|c|c|c|c|}
\hline Item & r-hitung & r-tabel & Ketetangan \\
\hline SOAL1 & 0,942 & 0,496 & Valid \\
\hline SOAL2 & 0,940 & 0,496 & Valid \\
\hline
\end{tabular}


Tabel 3 Hasil Correlations Uji Validitas

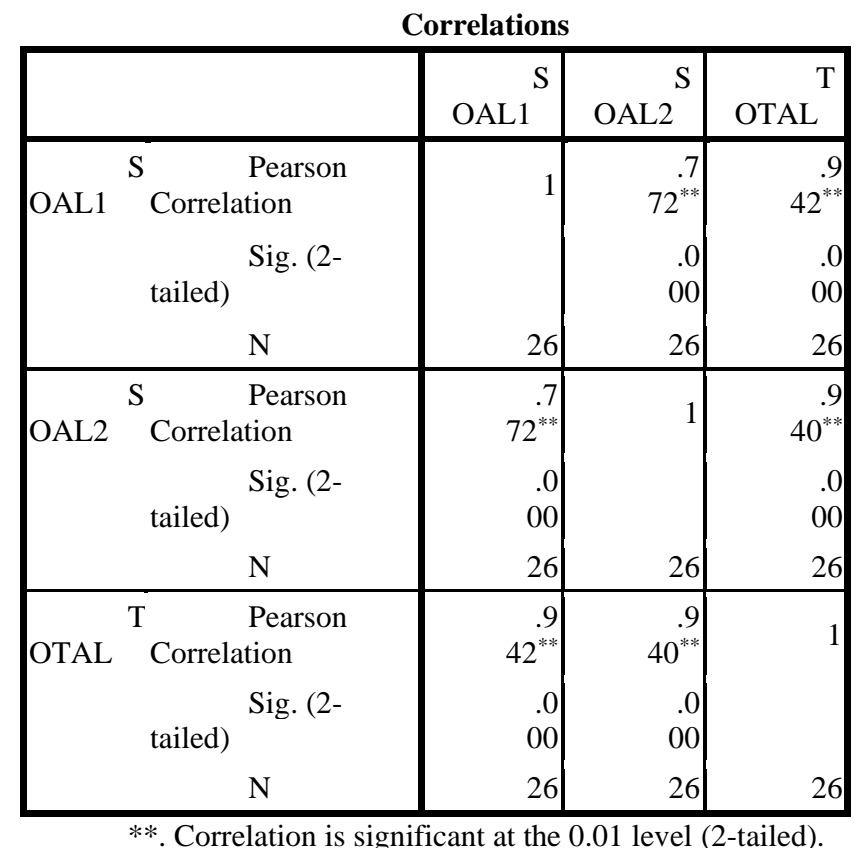

Hal tersebut dapat disimpulkan dengan melihat bahwa r-hitung lebih besar dibandingkan r-tabel. Bahwa dapat dinilai layak atau valid sehingga dapat dipergunakan untuk keperluan penelitian. Berikut hasil uji reliabilitas:

Tabel 5

\section{Hasil Uji Reliabilitas}

\begin{tabular}{|r|c|c|}
\hline \multicolumn{2}{|c|}{ Reliability Statistics } \\
Cronbach's & $\begin{array}{c}\text { Cronbach's } \\
\text { Alpha Based on } \\
\text { Standardized } \\
\text { Alpha }\end{array}$ & N of \\
Items & Items \\
\hline 871 & .871 & 2 \\
\hline
\end{tabular}

Berdasarkan hasil uji reliabiatabel nilai Alpha Cronbach dengan tabe klasifikasi nilai koefisian reliabilitas maka dapat disimpulkan bahwa instrumen pada penelitian ini adalah reliabilitas tinggi. (3) Pedoman wawancara, pertanyaan yang digunakan untuk wawancara ini dibuat oleh peneliti berdasarkan indikator komunikasi matematis dan dapat berkembang sesuai dengan kondisi. 
Lisa Cahyanti ${ }^{1}$, Sarwo Edy ${ }^{2}$ : Analisis Kemampuan Komunikasi Matematis...

\section{Deskripsi Tahap Pemilihan Subjek Penelitian}

Pemilihan subjek, peneliti akan memilih peserta didik kelas IV C. Alasan memilih kelas IV C karena didasarkan pada kondisi peserta didik. Pada pemilihan subjek di kelas IV $\mathrm{C}$, langkah pertama peneliti yaitu mengirim angket berupa link Google Form di grup WhatsApps kelas, selanjutnya peneliti mengambil 3 peserta didik sebagai subjek penelitian yang masing-masing memiliki kategori tinggi, sedang, dan rendah. Setelah menemukan subjek penelitian, peneliti memberikan tes kemampuan komunikasi matematis serta melakukan wawancara terhadap ketiga subjek tersebut.

\section{Deskripsi Tahap Pengumpulan Data}

Tahap pengumpulan data antara lain, (a) Pengumpulan data angket kecerdasan emosional, Pengumpulan data angket kecerdasan emosional peserta didik kelas IV C melalui link Google Form yang telah dikirim melalui grup WhatsApp dengan bantuan guru kelas. (b) Pengumpulan data melalui tes kemampuan komunikasi matematis, subjek penelitian yang telah dipilih diberikan soal tes kemampuan komunikasi matematis melalui WhatsApp untuk mengerjakan tes tersebut dengan soal yang berjumlah 3 soal. Peneliti memantau ketika pengerjaan tes kemampuan komunikasi matematis melalui video call WhatsApp secara langsung. hasil rekapitulasi dari data kemampuan komunikasi matematis peserta didik disajikan pada tabel dibawah ini:

\section{Tabel 6 Hasil Rekapitulasi Komunikasi Matematis}

\begin{tabular}{|c|c|c|c|c|c|c|c|c|c|c|c|}
\hline \multirow{4}{*}{$\begin{array}{l}\text { Nama } \\
\text { Inisial }\end{array}$} & \multirow{4}{*}{$\begin{array}{c}\text { Kategori } \\
\text { Kecerdasan } \\
\text { Emosional }\end{array}$} & \multicolumn{9}{|c|}{ Komunikasi Matematis } & \multirow{4}{*}{$\begin{array}{c}\text { Skor } \\
\text { Akhir }\end{array}$} \\
\hline & & \multirow{2}{*}{\multicolumn{3}{|c|}{$\begin{array}{c}\text { Soal } 1 \\
\text { Indikator }\end{array}$}} & \multirow{2}{*}{\multicolumn{3}{|c|}{$\begin{array}{c}\text { Soal } 2 \\
\text { Indikator }\end{array}$}} & \multirow{2}{*}{\multicolumn{3}{|c|}{$\begin{array}{c}\text { Soal } 3 \\
\text { Indikator }\end{array}$}} & \\
\hline & & & & & & & & & & & \\
\hline & & $\mathbf{I}$ & II & III & $\mathbf{I}$ & II & III & $\mathbf{I}$ & II & III & \\
\hline AR & Tinggi & 4 & 4 & 4 & 3 & 3 & 4 & 4 & 3 & 4 & 33 \\
\hline KM & Sedang & 3 & 3 & 4 & 3 & 3 & 4 & 3 & 3 & 2 & 28 \\
\hline $\mathrm{FH}$ & Rendah & 3 & 0 & 3 & 3 & 0 & 2 & 3 & 0 & 3 & 17 \\
\hline
\end{tabular}

(c) Pengumpulan data melalui wawancara, wawancara dilakukan setelah menyelesaikan tes kemampuan komunikasi matematis. Pelaksanaan wawancara berlangsung selama 30 menit melalui video call WhatsApp. 


\section{Tahap Analisis Data}

Tahapan ini dilakukan analisis data dan memaparkan hasil kemampuan komunikasi matematis peserta didik. (a) Analisis data kecerdasan emosional, terdapat peserta didik dengan tingkatan kecerdasan emosional tinggi sebanyak 15 peserta didik, peserta didik dengan tingkatan kecerdasan emosional sedang sebanyak 7 peserta didik, peserta didik dengan tingkatan kecerdasan emosional rendah sebanyak 4 peserta didik. Berdasarkan pada teknik pengambilan sempelnya yaitu purposive sampling, akan diambil 1 peserta didik dengan tingkatan kecerdasan emosional tinggi, 1 peserta didik dengan tingkatan kecerdasan emosional sedang, dan 1 peserta didik dengan tingkatan kecerdasan emosional rendah. (b) Analisis data kemampuan komunikasi peserta didik, diperoleh data nilai tes kemampuan komunikasi matematis peserta didik, selanjutnya dilakukan pengkategorikan supaya mengetahui kategori kemampuan komunikasi matematis. Hasil kategori kemampuan komunikasi matematis disajikan dalam bentuk tabel berikut ini:

Tabel 7 Hasil Kategori Kemampuan Komunikasi Peserta Didik

\begin{tabular}{|c|c|c|c|c|}
\hline \multirow{2}{*}{$\begin{array}{c}\text { Nama } \\
\text { Inisial }\end{array}$} & $\begin{array}{c}\text { Kategori } \\
\text { Kecerdasan } \\
\text { Emosional }\end{array}$ & \multicolumn{2}{|c|}{ Kemampuan komunikasi Matematis } & \multirow{2}{*}{ Kategori } \\
\cline { 3 - 5 } & & Skor Akhir & Nilai akhir & \\
\hline AR & Tinggi & 33 & 92 & Tinggi \\
\hline KM & Sedang & 28 & 78 & Sedang \\
\hline FH & Rendah & 17 & 47 & Rendah \\
\hline
\end{tabular}

\section{Analisis Tes Penyelesaian Soal Kemampuan Komunikasi Matematis}

Pada tahap ini, peneliti menganalisis hasil dari penyelesaian masalah matematika dan memaparkan hasil tes kemampuan komunikasi matematis peserta didik sebagai berikut;

(a) Deskriptif Kemampuan Komunikasi Matematis Dengan Peserta Didik Yang Memiliki Kecerdasan Emosional Tinggi.

Berdasarkan analisis yang telah dipaparkan, peserta didik dengan tingkat kecerdasan emosional tinggi dalam membaca soal sebanyak 1 sampai 2 kali. Dengan itu peserta didik tersebut mampu menjelaskan lagi dengan baik, benar, rinci, serta lengkap. Peserta didik ini 
Lisa Cahyanti ${ }^{1}$, Sarwo Edy ${ }^{2}$ : Analisis Kemampuan Komunikasi Matematis...

juga mampu mengilustrasikan gambar dengan sempurna dan lengkap pemberian nama bangun serta tanda sisi yang sama.

Dalam menafsirkan ide matematika, peserta didik ini mampu menyebutkan informasi pada soal permasalahan tersebut dengan tepat dan lengkap menyebutkan apa saja yang diketahui dan ditanyakan pada soal. Mampu memahami serta menghubungkan model matematika, serta memanggil kembali informasi yang telah diketahui dengan langkah yang sistematis dan runtut dalam menyelesaikan soal. Selain itu peserta didik ini mampu menjelaskan jawabannya dengan baik rinci dan benar. Mampu memberikan kesimpulan evaluasi hasil dari jawaban dengan benar dan lengkap.

Sehingga peserta didik dengan kecerdasan emosional tinggi juga memiliki kemampuan komunikasi matematis yang tinggi pula, sebab mampu menyelesaikan soal dengan baik, tepat, sistematis, dan lengkap

(b) Deskriptif Kemampuan Komunikasi Matematis Dengan Peserta Didik Yang Memiliki Kecerdasan Emosional Sedang.

Berdasarkan analisis yang telah dipaparkan, peserta didik dengan tingkat kecerdasan emosional sedang dalam membaca soal sebanyak 3 sampai 4 kali. Mampu menyatakan benda nyata dan menggambarkan ke dalam ide matematika hampir tepat dan lengkap. Akan tetapi kurang lengkap pemberi nama bangun.

Peserta didik dengan kemampuan komunikasi sedang ini mampu menafsirkan ide matematika dengan menyebutkan semua informasi yaang ada pada soal apa saja yang diketahui serta apa yang ditanyakan. Dalam menyelesaikan permasalahan soal mampu menyelesaikan dengan runtut. Penjelasannya tepat tetapi masih ada kekurangan. Pada kesimpulan pemberian evaluasi jawaban yang telah dihitung tidak sesuai dengan kesimpulan yang telah ditulis.

Sehingga peserta didik dengan kecerdasan emosional sedang juga memiliki kemampuan komunikasi matematis yang sedang pula, sebab mampu menyelesaikan soal hampir tepat, sistematis, dan lengkap.

(c) Deskriptif Kemampuan Komunikasi Matematis Dengan Peserta Didik Yang Memiliki Kecerdasan Emosional Rendah. 
Berdasarkan analisis yang telah dipaparkan, peserta didik dengan tingkat kecerdasan emosional rendah dalam membaca soal lebih dari 3 kali. Mampu menyatakan benda nyata dan menggambarkan ke dalam ide matematika hampir tepat dan lengkap. Akan tetapi kurang lengkap pemberi nama bangun.

Peserta didik dengan kemampuan komunikasi rendah ini mampu menafsirkan ide matematika namun sulit dalam menyebutkan informasi yang ada pada soal apa yang diketahui serta apa yang ditanyakan. Dalam menyelesaikan permasalahan soal mampu menyelesaikan dengan runtut. Namun tidak memberikan satuan luas pada jawaban. Tidak memberikan kesimpulan evaluasi jawaban yang telah dikerjakan.

Sehingga peserta didik dengan kecerdasan emosional rendah juga memiliki kemampuan komunikasi matematis yang rendah pula, sebab kesulitan dalam menyetakan informasi dan kurang tepat dalam menyelesaikan soal.

\section{KESIMPULAN, DISKUSI DAN REKOMENDASI}

Berdasarkan pemaparan dari analisis data dan pembahasan, maka dapat disimpulkan bahwa, Peserta didik dengan tingkat kecerdasan emosional tinggi, memiliki kemampuan komunikasi matematis yang tinggi pula. Peserta didik mampu mengilustrasikan gambar dengan sempurna dan lengkap pemberian nama bangun serta tanda sisi yang sama. Mampu menyebutkan apa saja yang diketahui dan ditanyakan pada soal. Mampu memahai serta menghubungkan model matematika, serta memanggil kembali informasi yang telah diketahui dengan langkah yang sistematis dan runtut dalam menyelesaikan soal. Mampu memberikan kesimpulan evaluasi hasil dari jawaban dengan benar dan lengkap.

Peserta didik dengan tingkat kecerdasan emosional sedang, memiliki kemampuan komunikasi matematis yang sedang. Peserta didik mampu mengilustrasikan serta menggambarkan ke dalam ide matematika hampir tepat dan lengkap. Akan tetapi kurang lengkap pemberi nama bangun persegi panjang. Mampu menafsirkan ide matematika dengan menyebutkan semua informasi soal apa saja yang diketahui serta apa yang ditanyakan. Mampu menyelesaikan permasalahan soal dengan runtut. Pada kesimpulan pemberian evaluasi jawaban yang telah dihitung tidak sesuai dengan kesimpulan yang telah ditulis. Peserta didik dengan tingkat kecerdasan emosional rendah, memiliki kemampuan 
Lisa Cahyanti ${ }^{1}$, Sarwo Edy ${ }^{2}$ : Analisis Kemampuan Komunikasi Matematis...

komunikasi matematis yang rendah. Mampu menyatakan benda nyata dan menggambarkan ke dalam ide matematika hampir tepat dan lengkap. Akan tetapi kurang lengkap pemberi nama bangun segitiga. Mampu menafsirkan ide matematika namun sulit menuliskan dalam menyebutkan informasi yang ada pada soal apa yang diketahui serta apa yang ditanyakan. Dalam menyelesaikan permasalahan soal mampu menyelesaikan dengan runtut. Namun tidak memberikan satuan luas pada jawaban. Tidak memberikan kesimpulan evaluasi jawaban yang telah dikerjakan.

Sebelum penelitian "Analisis Kemampuan Komunikasi Matematis Peserta Didik SD Dalam Menyelesaikan Soal Matematika Ditinjau Dari Kecerdasan Emosional” terdapat penelitian yang sebelumnya oleh peneliti Satriani (2015) dengan jedul "Pengaruh Kecerdasan Emosional Terhadap Prestasi Belajar Matematika Siswa Kelas IV di SD Negeri Rojowinangun 1 Yogyakarta”. Membahas tentang prestasi belajar dengan memperhatikan kecerdasan emosional peserta didik. Sedangkan penelitian ini yaitu mengetahui komunikasi matematis peserta didik terhadap kecerdasan emosional yang berbeda - beda.

Rekomendasi penelitian ini yaitu bisa dijadikan referensi atau sebagai acuan dalam penelitian lain supaya menjadikan penelitian yang serupa ini lebih baik lagi.

\section{UCAPAN TERIMA KASIH}

Penulis mengucapkan terimakasih kepada:

- Bapak Dr. Sarwo Edy, M.Pd selaku Dosen pembimbing 1 yang telah bimbingan, arahan, saran, dan motivasi selama penyusunan skripsi ini.

- Bapak Syaiful Huda, M. Si selaku Dosen pembimbing 2 sekaligus Ketua Program Studi Pendidikan Matematika yang telah bimbingan, arahan, saran, dan motivasi selama penyusunan skripsi ini.

- Teman-teman pejuang skripsi'16 Pendidikan Matematika Terbit Fajar angkatan 2016 yang memberikan semangat, do'a, bantuan, dan menampung keluh kesah selama menulis skripsi ini. 


\section{DAFTAR PUSTAKA}

Charankumar, V. (2015). Emotional Intelligence of Primary School Teachers. internasional Journal of Engineering Resear And Management (IJERM) ISSN:2349-2058 Vol.2.

Goleman, D. (2015). Emotional Intelligence: Mengapa EI Lebih Penting Dari IQ. Jakarta: Gramedia Pustaka Utama.

Mahmudi, A. (2006). Pengembangan Kemampuan Komunikasi Matematika peserta didik Melalui Penmbelajaran.

NCTM. (2000). Participles and Standatds for School Mathematics. United States of America: ISBN 0-87353-480-8.

Noriah, M. Z. (2004). kecerdasan emosional di kalangan pekerja di Malaysia. laporan teknikal, prosiding IPRA.

Satriani, R. D. (2015). Pengaruh Kecerdasan Emosional Terhadap Prestasi Belajar Matematika Siswa Kelas IV di SD NEGERI ROJOWINANGUN I Yogyakarta.

Sudjana, N. (2005). Metode Penelitian Kuantitatif, Kualitatif, dan R\&D . Bandung: PT. Remaja Rodaskarya. 